\title{
Effects of an Unusual Cold-Water Intrusion in 2008 on the Catch of Coastal Fishing Methods around Penghu Islands, Taiwan
}

\author{
Ming-An Lee ${ }^{1,2}$, Yi-Chou Yang ${ }^{1}$, Yi-Lo Shen ${ }^{3}$, Yi Chang ${ }^{4, *}$, Wann-Sheng Tsai ${ }^{3}$, \\ Kuo-Wei Lan ${ }^{1}$, and Yi-Chun Kuo ${ }^{1}$ \\ ${ }^{1}$ Department of Environmental Biology and Fisheries Science, National Taiwan Ocean University, Keelung, Taiwan \\ ${ }^{2}$ Center of Excellence for Oceans, National Taiwan Ocean University, Keelung, Taiwan \\ ${ }^{3}$ Penghu Marine Biology Research Center, Fisheries Research Institute, Council of Agriculture, Penghu, Taiwan \\ ${ }^{4}$ Institute of Ocean Technology and Marine Affairs, National Cheng Kung University, Tainan City, Taiwan
}

Received 13 April 2013, accepted 6 August 2013

\begin{abstract}
Based upon long-term observations (1993 - 2010) of satellite-derived winter sea surface temperature (SST) data, an exceptional cold-water intrusion into the southern Taiwan Strait (TS) was noted in February 2008. In the winter of 2008, La Niña caused a strong and continuous northeasterly wind that drove the cold ocean current, the China Coastal Current, more southward to penetrate the southern TS north of the Chang-Yuen Ridge. A portion of this current turned eastward to the south of Penghu Islands (PHI). The low-SST event significantly impeded local marine aquaculture and wild fish, causing the death of more than 73 tons of fish around PHI. Comparing variations of the first quarterly catches in 2008 with the long-term averages from 1993 to 2010 (excluding 2008), we noted a 50 to 80\% decrease in catches from pole-and-line, long-line, and gill-net fishery. Non-migratory species dominated the composition of the catches. We also noted a greater than $230 \%$ increase in the catches from set-net fishery, with the majority being migratory species. These results illustrate the positive and negative effects of cold-water intrusion on several fish communities and species.
\end{abstract}

Key words: Sea surface temperature, La Niña, Taiwan Strait, China Coastal Current

Citation: Lee, M. A., Y. C. Yang, Y. L. Shen, Y. Chang, W. S. Tsai, K. W. Lan, and Y. C. Kuo, 2014: Effects of an unusual cold-water intrusion in 2008 on the catch of coastal fishing methods around Penghu Islands, Taiwan. Terr. Atmos. Ocean. Sci., 25, 107-120, doi: 10.3319/TAO.2013.08.06.01(Oc)

\section{INTRODUCTION}

The influence of climate change on the world's oceans is characterized by rapid changes in marine environments and responses of marine organisms. These effects may include changes in sea surface temperature (SST) and hydrological patterns, the occurrence of rare, extreme oceanic events, and decreases in marine fish populations (Yatsu et al. 2005; Lloret et al. 2008; Knutson et al. 2010). Previous studies have focused primarily upon open oceanic waters, and have only occasionally discussed the relationship between variations of fish abundance and climate change in coastal and regional waters (Akiyanma and Saitoh 1993; Parsons and Lear 2001; Edwards et al. 2002; Takasuka et al. 2007). Akiyanma and Saitoh (1993) noted that an onshore meander of the Kuroshio front developed into a Kuroshio

\footnotetext{
* Corresponding author

E-mail:yichang@mail.ncku.edu.tw
}

warm-water intrusion that lasted for 8 - 10 days with a sharp increase of water temperature of approximately 2 to $3^{\circ} \mathrm{C}$ along the Japanese coast in the northwestern Pacific. This change of water temperature was closely related to the formation of a fishing ground of pelagic fish in the shelf slope region. La Niña caused a strong wind that caused the cold China Coastal Current (CCC) to penetrate into the southern Taiwan Strait (TS); a portion of this current turned eastward to the south of Penghu Islands (PHI) (Chang et al. 2009). Hsieh et al. (2008) and Chang et al. (2009) noted the occurrence of a strong wind with speeds of more than $6 \mathrm{~m} \mathrm{~s}^{-1}$, lasting longer than 2 weeks in February 2008, which then resulted in an extremely low SST event which harmed the local aquaculture and coral reef ecosystem in the waters surrounding the PHI. Liao et al. (2013) deduced the mechanism of cold-water intrusion using a regional ocean model. Their results suggested that the offshore movement of a cold current was related to the southward gradients of sea level 
and density. The cold current overcame the onshore Ekman transport caused by the northeasterly monsoon. To adapt regional environmental change for the mariculture industry, Chang et al. (2013) suggested setting up an early warning system for decision makers in fishery agencies to perform time-adaptive measures. However, the relationship between catches of fish and extreme changes in the marine environment is yet to be understood. Therefore, this study examines fishing data to investigate the effects of specific climate forces on the coastal fisheries of the southern TS.

The TS connects the East China Sea (ECS) with the South China Sea (SCS) between Taiwan and China (Fig. 1) in the western Pacific Ocean. A distinct topographic feature of the TS is the Chang-Yuen Ridge (CYR), which extends westward from the middle of the west coast of Taiwan. It divides the TS into 2 basins and creates a boundary that allows the passing of the CCC from the north, and the South China Sea Warm Current (SCSWC) and Kuroshio Branch Current (KBC) from the south during winter and summer (Jan et al. 1998). Another important feature is the Penghu Channel (PHC), which is a north-south submarine channel that is more than $60 \mathrm{~m}$ in depth and located between the PHI and Taiwan. The PHC guides the KBC and SCSWC as they

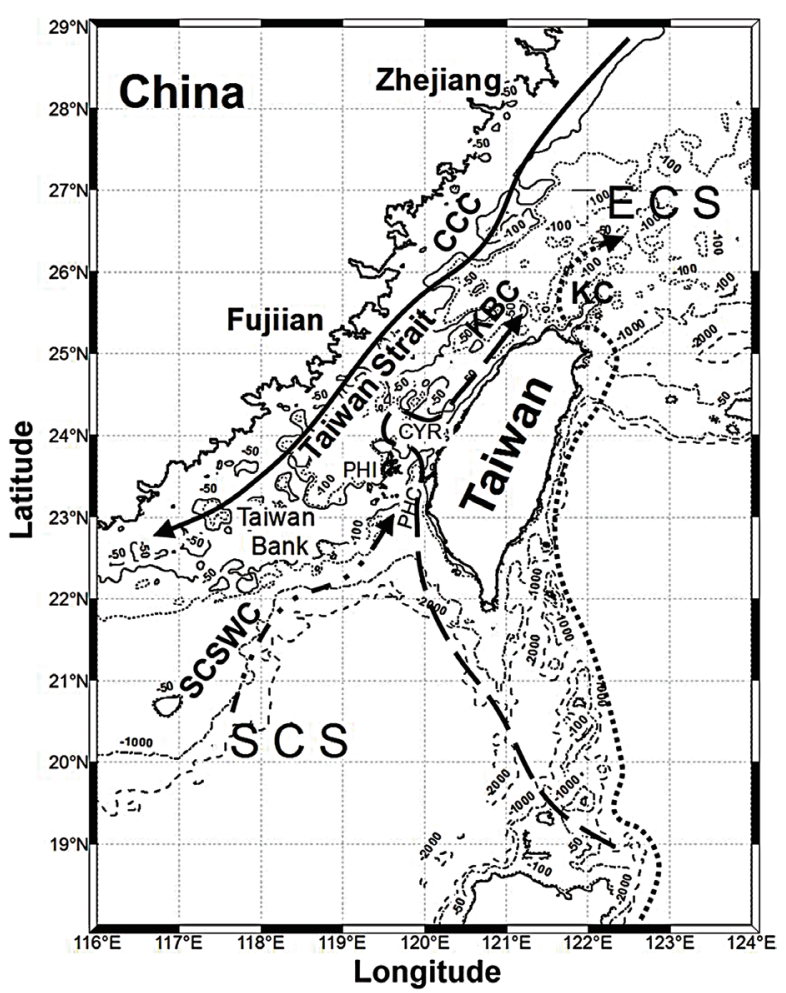

Fig. 1. Map of the study area with bathymetric contours (meters) and schematic view of the current circulation (modified from Tang et al. 2000; Jan et al. 2002). Solid line: China Coastal Current (CCC); dashed line: Kuroshio Branch Current (KBC); dashed-dotted line: South China Sea Warm Current (SCSWC); dotted line: Kuroshio Current (KC). East China Sea (ECS); South China Sea (SCS); Chang-Yun Ridge (CYR); Penghu Islands (PHI); Penghu Channel (PHC). pass northwardly through the TS from the SCS to the ECS (Wang and Chern 1992). The ECS and SCS exchange water and nutrient fluxes through the TS (Liu et al. 2000).

However, the flow patterns of the TS change in winter (Fig. 1). The CCC, mainly in the western TS, moves southward along the Chinese coast. A portion of the current is blocked around the CYR and returns northward at the expense of the southward intrusion (solid line; Jan et al. 2002). Moreover, the CYR blocks the KBC in the PHC. Previous studies (Lee et al. 2003; Kuo and Ho 2004; Lee et al. 2005b) on SST patterns in the TS indicated that the dominant spatial variance in SST was consistent with a quasi-permanent front at the CYR during winter (Chang et al. 2006). Tzeng et al. (2012) noted that average SSTs at the CYR were positively correlated with latitudinal variations of the $20^{\circ} \mathrm{C}$ isotherm, implying that SST variability at the CYR could be an indicator of annual variation of the CCC in the eastern TS. Furthermore, Jan et al. (2002) suggested that a warm tongue of the $\mathrm{KBC}$ occasionally advances northward from the PHC. Most previous studies have suggested that the cold CCC is generally blocked north of the CYR during winter, but waters south of the ridge are highly saline and warm.

Seasonal current circulation patterns and extreme climate events that occur during El Niño or La Niña events affect the SSTs and the TS. These events are characterized by increasing water temperature during $\mathrm{El}$ Niño and abnormally decreasing water temperature during La Niña (Kuo and Ho 2004). In general, the SST in the southern TS is higher than $20^{\circ} \mathrm{C}$ during winter, but decreased to $13^{\circ} \mathrm{C}$ between the end of January and mid-February in 2008. This extreme thermal anomaly significantly affected marine ecology and fisheries (Anonymous 2008). During January and February 2008, significant numbers of resident fish died and washed up on the beaches around PHI in the southern TS. More than 183 species in 58 families were recognized, including significant amounts of high-priced species, such as the grouper, parrotfish, and wrasses (Hsieh et al. 2008). Several studies suggested that an exceptional intrusion of cold CCC because of climate change caused this ecological disaster (Hsieh et al. 2008; Chang et al. 2009). Mora and Ospina (2002) indicated that cold-water events in the eastern Pacific Ocean in a La Niña year induced negative effects on the composition and abundance of marine organisms, which was particularly significant for several reef fish because the water temperature decreased below their critical thermal minimum $\left(16.3^{\circ} \mathrm{C}\right)$. Changes in water temperature during La Niña can cause more intense variations in hydrographic features than those during El Niño. Effects of La Niña winters on the marine populations and fisheries in the TS are not properly understood.

This study examines the effects of a cold-temperature event in a La Niña winter on the coastal fisheries by analyzing long-term SST, wind, and fishery data in relation to oceanic environmental data. 


\section{DATA AND METHODS}

Fishing data of January to June 1993 to 2010 were collected from the Penghu Fishery Association. The 4 major types of fishing methods in the waters around PHI were pole-and-line, gill-net, long-line, and set-net. The compositions of these 4 fishing methods were recorded from 2006 to 2010 using questionnaires, and classified into non-migratory and migratory species (http://fishdb.sinica.edu.tw/). The fishing data were normalized by catch per unit effort (CPUE) against long-term variations in environmental factors to evaluate the influence of this exceptional cold-water intrusion. The CPUE ${ }_{(\mathrm{kg} / \mathrm{day})}$ for each fishing method was calculated as follows:

$\mathrm{CPUE}_{\text {(pole-and-line) }}=C w / A$

$\mathrm{CPUE}_{\text {(gill-net) }}=C w / B$

$\mathrm{CPUE}_{\text {(long-line) }}=C w / C$

$\mathrm{CPUE}_{\text {(set-net) }}=C w / D$

The catch weight in $\mathrm{kg}$ is $C w$. The number of hooks is given as $A$, nets as $B$, per 1000 hooks as $C$, and hauls as $D$.

Satellite-derived winter SST data measured by advanced very-high-resolution radiometer (AVHRR) sensors during the 18-year period from 1993 to 2010 were collected from the National Oceanic and Atmospheric Administration (NOAA) Satellite Active Archive (http://www.class.ngdc. noaa.gov), and the regional AVHRR data library at the National Taiwan Ocean University (NTOU), Keelung, Taiwan (Lee et al. 2005a). The Multichannel Sea Surface Temperature (MCSST) algorithm produced the SST images at a spatial resolution of $1.1 \mathrm{~km}$ (McClain et al. 1985).

Large-scale environmental factors of the Oceanic Niño Index (ONI, http://www.cpc.noaa.gov/products) were used as indicators of El Niño or La Niña events from January 1993 to December 2010 to investigate the effects of regional environmental variations on fishing method. Wind data as recorded by a gauge station at the PHI were used in this study. A 7-day moving average of wind speed was compared with daily mean SST changes in the TS. Daily SST variations were calculated by averaging the SST of the $0.5^{\circ}$ square northwest of PHI, in the center of TS $\left(23.5-24.0^{\circ} \mathrm{N}\right.$, $\left.119.0-119.5^{\circ} \mathrm{E}\right)$.

The Hybrid Coordinate Ocean Model (HYCOM) (Bleck 2002) is a primitive equation of the general circulation model. The HYCOM with a $1 / 12^{\circ}$ horizontal resolution at the equator (approximately $7 \mathrm{~km}$ at mid-latitudes) is the ocean model component of an eddy-resolving operational forecast system. In this study, HYCOM data were used to simulate the differences of current circulation and water temperature at 20 -m depth in the TS.

\section{RESULTS}

\subsection{Winter SST Patterns}

The long-term monthly mean SST during winter
(Figs. $2 \mathrm{a}-\mathrm{c})$ showed that the cold $\mathrm{CCC}\left(<18^{\circ} \mathrm{C}\right)$ generally flows southward along the Chinese coast and creates a cold-water extension in January (Fig. 2a). Conversely, the warm $\mathrm{KBC}$ and SCSWC $\left(>20^{\circ} \mathrm{C}\right)$ moved northward to an area around the PHI in the eastern TS. In addition, the cold water extended to the northern edge of the CYR in February (Fig. 2b; black arrow). In contrast with the cold CCC, warm water $\left(>22^{\circ} \mathrm{C}\right)$ flowed northward into the eastern TS from the SCS through the PHC. This warm-water mass extended northward along the edge of the CYR and was blocked by the cold-water extension in the north.

Compared with monthly SST of the 18-year average, Figs. $2 \mathrm{~d}-\mathrm{f}$ show the spatial variances in SST during the winter of 2008. January 2008 (Fig. 2d) was approximately $1{ }^{\circ} \mathrm{C}$ warmer than the 18 -year average of the TS. A maximal SST difference $\left(>5^{\circ} \mathrm{C}\right)$ was noted in the CYR of the central Strait (Fig. 2d; yellow color). Figure 2d shows a significant cooling of the SST in the TS in February 2008. The SST along the Chinese coast was approximately $3.5^{\circ} \mathrm{C}$ lower (Fig. 2d; light blue), and in the northern TS $>7^{\circ} \mathrm{C}$ lower (Fig. 2e; white arrow) than the 18-year average. This distinct cold-water feature extended into the waters around PHI. The decreasing southward movement of the cold CCC in March, coupled with further northward movement of warm currents from the southern TS, resulted in the sharp SST front between the cold coastal water of the CCC and warm water of the TS (Fig. 2f; red color band).

The February SST fields in 2008 differed from the typical features of the 18 -year average. It was $3^{\circ} \mathrm{C}$ higher in January 2008 than the long-term average (Fig. 2d) but approximately $8^{\circ} \mathrm{C}$ lower (Fig. 2e; white arrow) in February 2008. Moreover, the SST in March 2008 showed a significant increase as indicated by a long band along the Chinese coast (Fig. 2f).

\subsection{Variations in SST, Wind Speeds, and the ONI}

Figure 3 shows the long-term SST (gray line) variations in the study area in comparison with wind speed (dotted line) and ONI (black line). Positive values of the ONI based on a threshold of $0.5^{\circ} \mathrm{C}$ indicate El Niño events, and negative values indicate La Niña events. These values show that SSTs are varied without a significant relationship with the trend of ONI. However, SST in February was warmer in El Niño winters (1995, 1998, 2003, 2005, 2007, and 2010) and cooler in La Niña winters (1996, 1999, 2000, and 2008). The northeasterly wind speed and ONI are negatively correlated with an $R^{2}$ of 0.31 , as shown in Fig. 3b, implying wind speeds are higher in La Niña winters (negative ONI value) than in El Niño winters (positive ONI value). Furthermore, the monthly SST of February in El Niño and in La Niña years was examined (Fig. 4). We chose the $20^{\circ} \mathrm{C}$ isotherm as an index of the winter thermal front boundary of $\mathrm{CCC}$ and $\mathrm{KBC}$ in the TS (Lee et al. 2005b) to represent the 
(a)

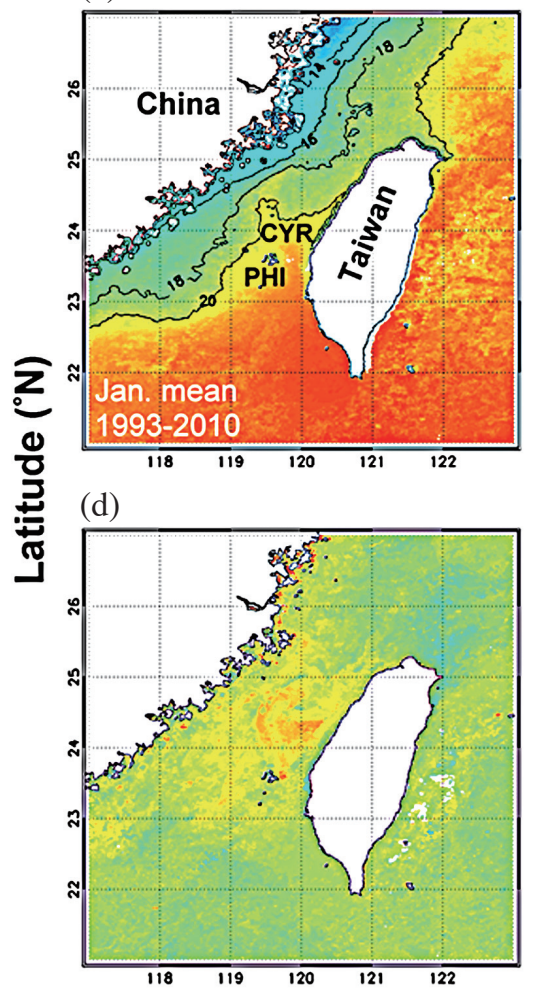

(b)

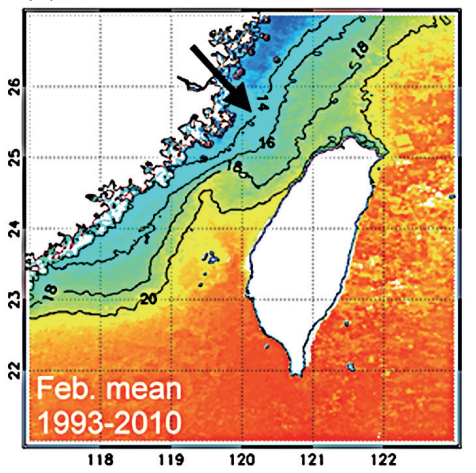

(e)

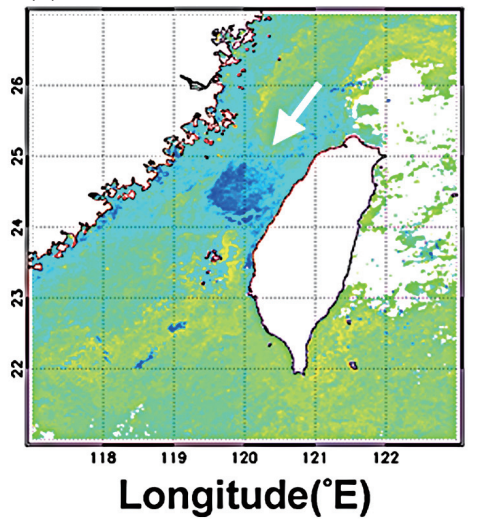

(c)

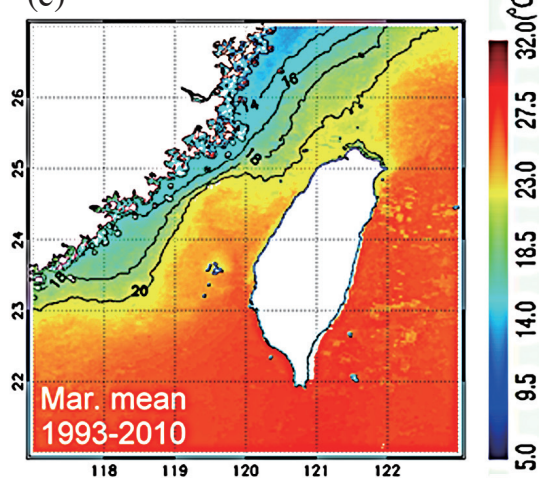

(f)

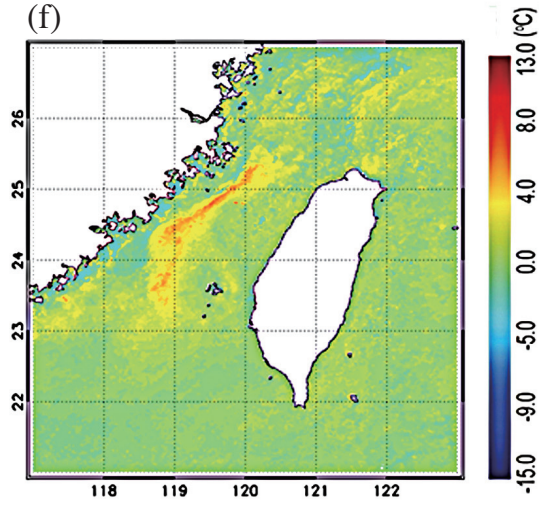

Fig. 2. Upper panel: Long-term monthly sea surface temperature (SST) averages for (a) January, (b) February, and (c) March of 1993 - 2010. Lower panel: difference of SST between 2008 and 18-year average for (d) January, (e) February, and (f) March of 2008. The SST difference is the respective monthly mean of 2008 minus the 18 -year monthly mean.

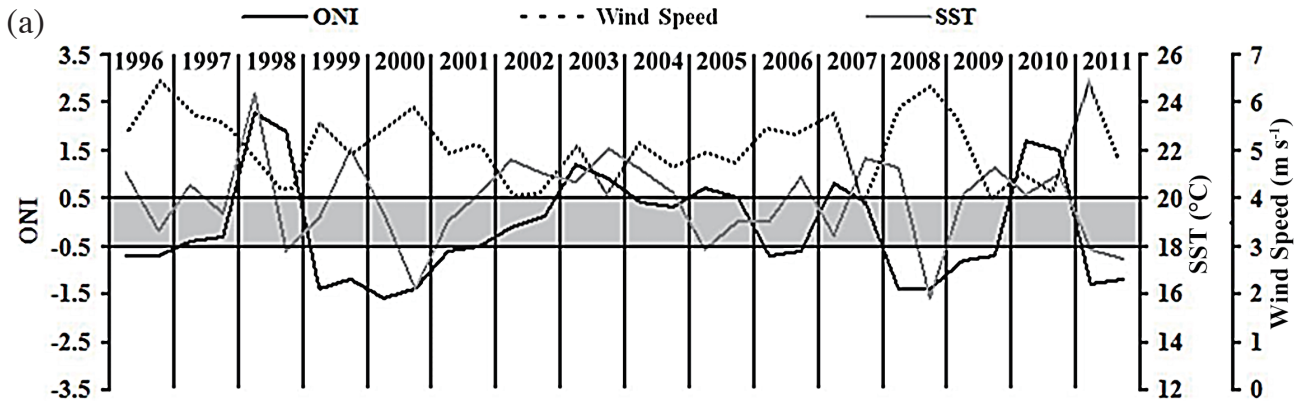

$\begin{array}{lllllllllllllllllllllllllllllllll}1 & 2 & 1 & 2 & 1 & 2 & 1 & 2 & 1 & 2 & 1 & 2 & 1 & 2 & 1 & 2 & 1 & 2 & 1 & 2 & 1 & 2 & 1 & 2 & 1 & 2 & 1 & 2 & 1 & 2 & 1 & 2\end{array}$

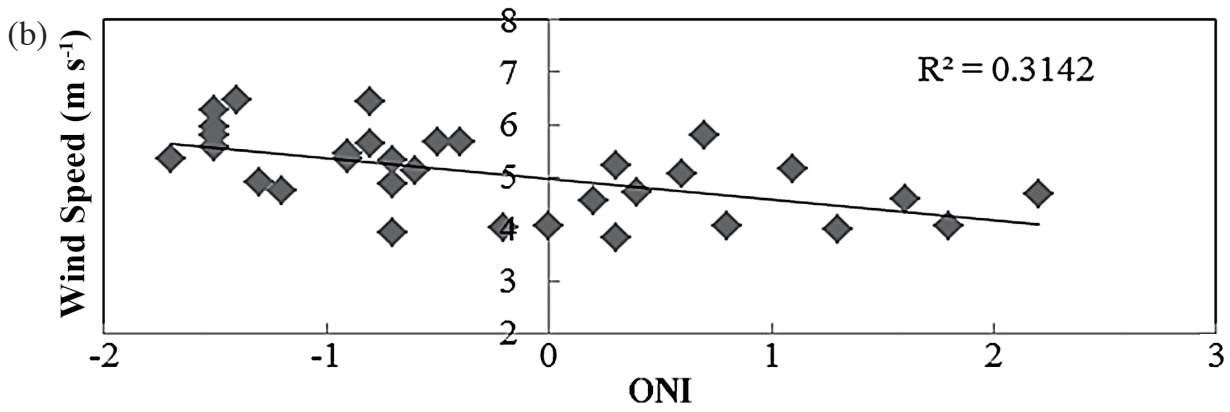

Fig. 3. (a) Black line: time series of the Oceanic Niño Index (ONI); gray line: sea surface temperature (SST); dotted line: wind speed in January and February of 1993 - 2010. Years with ONI above the shaded area indicate El Niño years. Years with ONI below the shaded area indicate La Niña years. The remaining shaded areas are normal years. (b) Scatter plot showing ONI versus wind speed. 

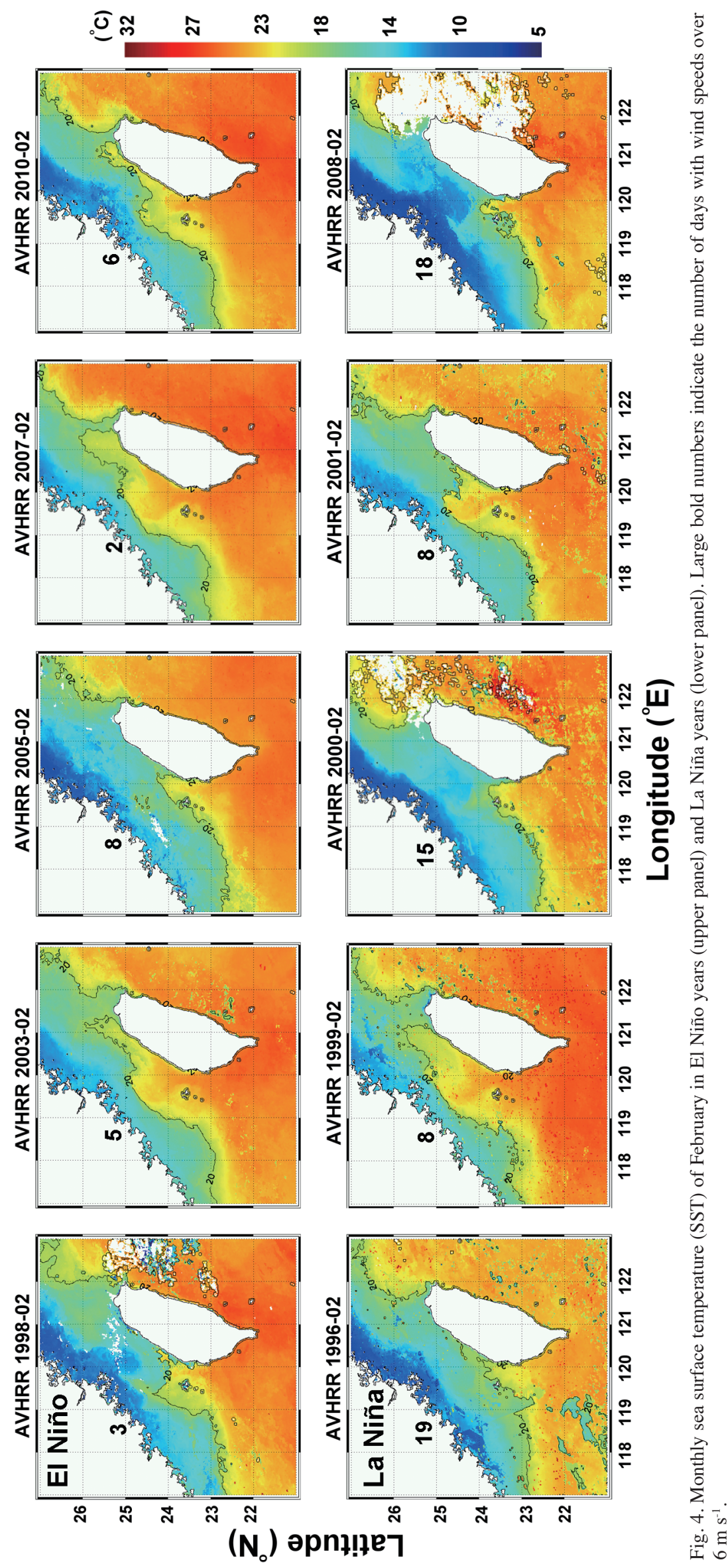
confinement of $\mathrm{KBC}$ by the intrusion of cold CCC. As shown in Fig. 4 , the $20^{\circ} \mathrm{C}$ isotherm passes over $24^{\circ} \mathrm{N}$ in the $5 \mathrm{El}$ Niño winters. The duration of the strong wind during these years is always less than 9 days. However, three La Niña winters $(1996,2000$, and 2008), recorded wind speeds of more than $6 \mathrm{~m} \mathrm{~s}^{-1}$ for over 15 days, when the $20^{\circ} \mathrm{C}$ isotherm was confined to the south of $24^{\circ} \mathrm{N}$. It was discovered that the ENSO event can affect the East Asian monsoon through the atmosphere-SST and mid latitude-tropical interactions (Wang et al. 2000; Pan et al. 2002). Our study suggests that this influence on the TS depends on wind duration.

\subsection{Effects of Cold Water on Fisheries}

The exceptional southerly intrusion of cold water in February 2008 sharply decreased SST and resulted in an ecological disaster. Sea currents washed tons of fish onto the beaches (Figs. 5a - c). The Environmental Protection Bureau (EPB) of Penghu County disposed of more than 73 tons of dead fish off the coast of PHI (Figs. 5d, 6). This event seriously hampered cage aquaculture, causing the deaths of more than 500 tons of cultured fish (Fig. 5e). The monthly catch of 4 major types of coastal fisheries (Fig. 7a: poleand-line; b: long-line; c: gill-net; and d: set-net) in Penghu from January to June were used to evaluate the effects of cold SST events on fisheries. Figure 7 compares the variations of catches during 2008 (solid bars) with the long-term averages (1993 - 2010, excluding 2008; open bars). The catches of the first three fisheries in 2008 (Figs. 7a - c) were significantly lower than the long-term averages. Whereas the figures for set-net fishery (Fig. 7d) were higher in January, February, and March than the long-term averages, they were lower in April, May, and June.

Daily CPUE values and species compositions from the questionnaire of the 4 fishing methods from January to March of 2006 to 2010 were analyzed (Table 1). The daily mean CPUE of the set-net method was approximately $1500 \mathrm{~kg} \mathrm{net}^{-1}$, and those of the pole-and-line, long-line, and gill-net methods were $4.65 \mathrm{~kg}^{\text {hook }}{ }^{-1}, 24.7{\mathrm{~kg} 1000^{-1}}^{-1}$ hooks, and $26.38 \mathrm{~kg} \mathrm{net}^{-1}$, respectively. The species composition caught with the gill-net was relatively more complex than that of the pole-and-line, long-line, and set-net. The 5 dominant taxa of fish caught with gill nets were Caesio caerulaureus (blue-and-gold fusilier), which accounted for $18.5 \%$ of the total catch by weight; Scomberomorus commerson (narrow-barred Spanish mackerel) accounted for 16.9\%; Seriola dumerili (greater amberjack) and Scomberromorus guttatus (Indo-Pacific king mackerel) accounted for $6.2 \%$ each; and Gerres sp. (silverbiddy fish) accounted for $5.1 \%$. The 2 most dominant taxa of the set-net method were Katsuwonus spp. (skipjack tuna, 32.2\%) and Trichiurus lepturus (hairtail fish, 23.7\%). The Aluterus monoceros (unicorn leatherjacket, $38.4 \%$ ) and Parapristipoma trilineatum (three-lined grunt, 22.2\%) were the dominant taxa of

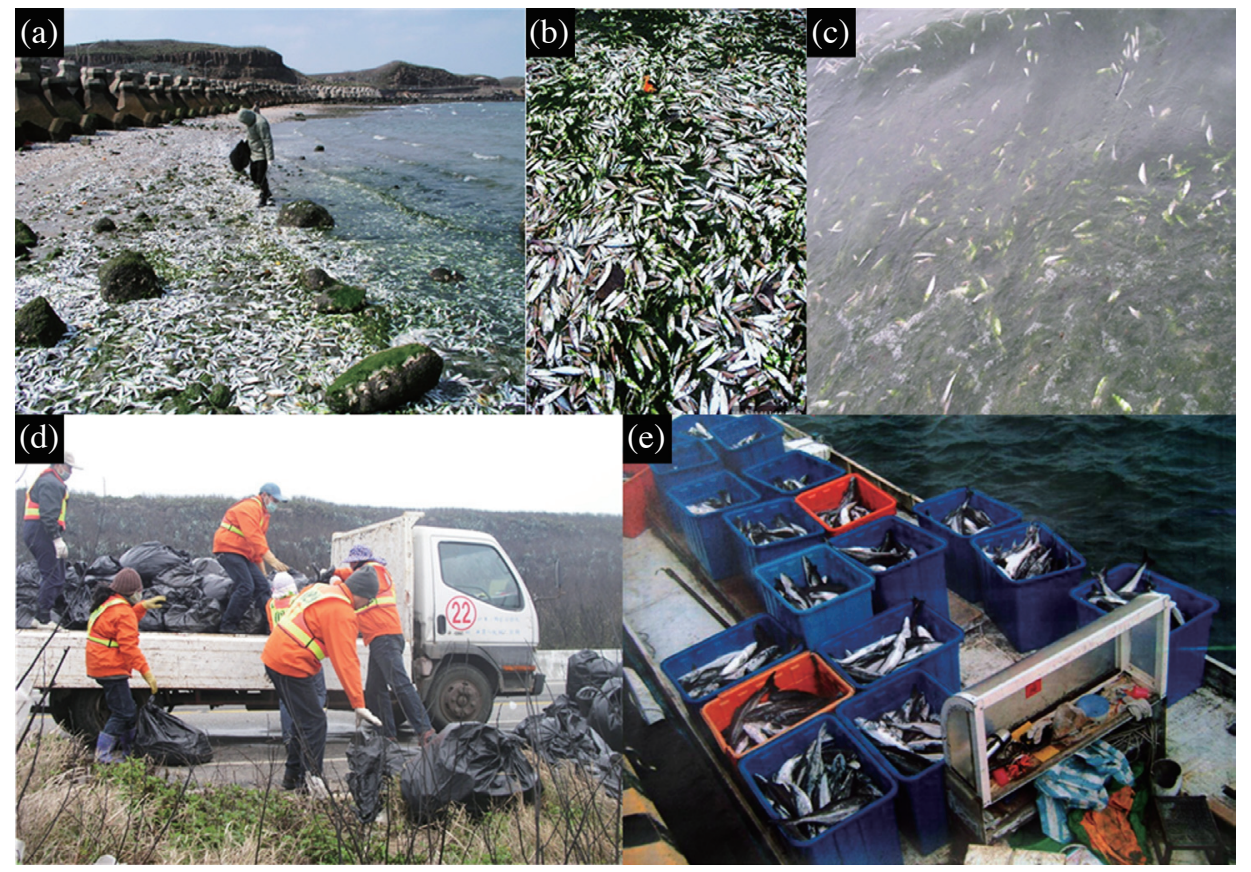

Fig. 5. (a - c) The unusual cold-water intrusion into the waters around Penghu Islands (PHI) caused extremely high rates of fish deaths in February 2008; (d) Environmental Protection Bureau (EPB) of Penghu County used trucks to remove bags of dead fish; and (e) Cobia remained from the cage culture. All pictures were reproduced with permission from Anonymous (2008). 


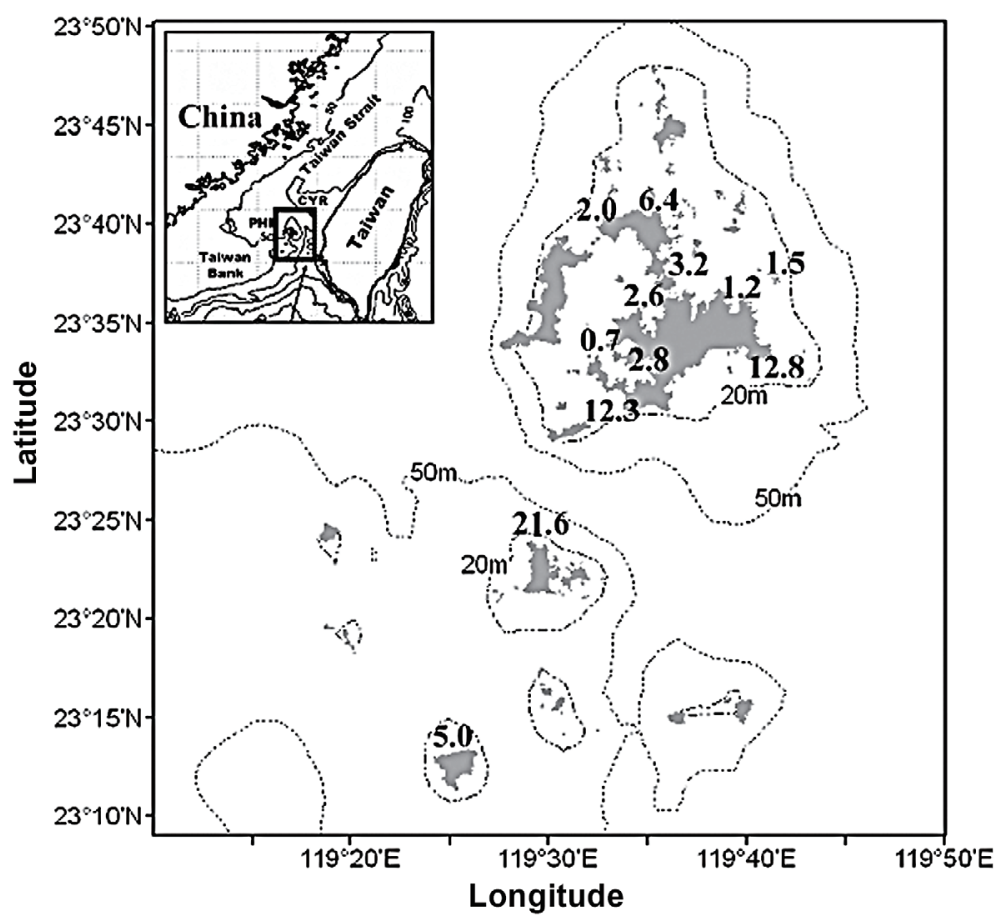

Fig. 6. Distribution of dead fish on the coast around Penghu Islands (PHI) during the cold sea surface temperature (SST) event in February 2008. Bold black numbers indicate the weight (tons) and geographic locations of dead fish recorded by the Environmental Protection Bureau (EPB) of Penghu County.

(a)

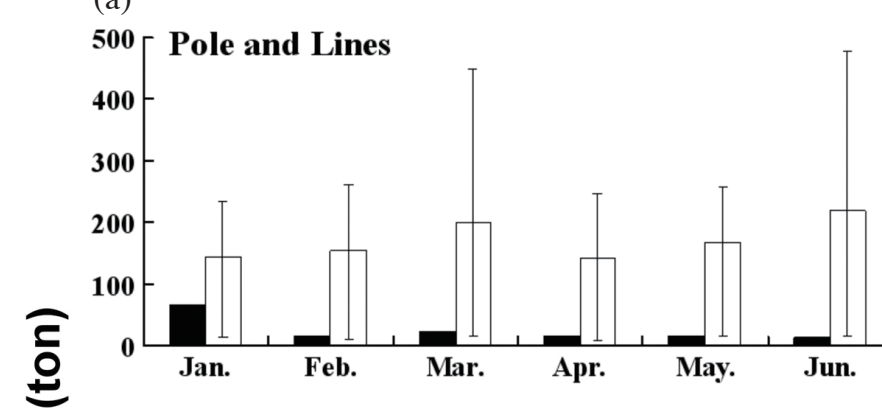

(c)

ऽับ 1000

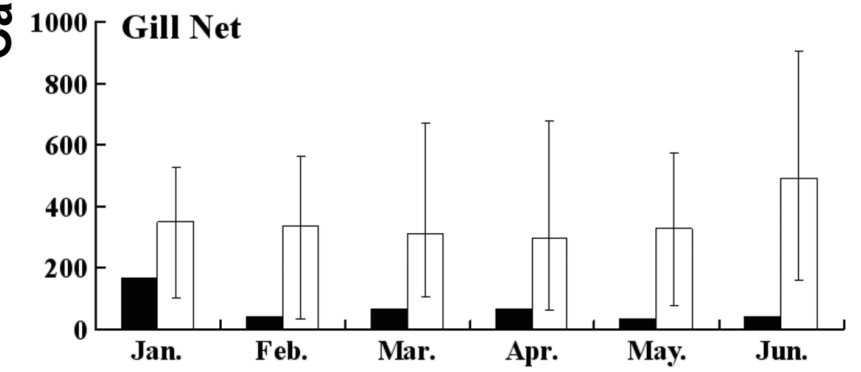

(b)

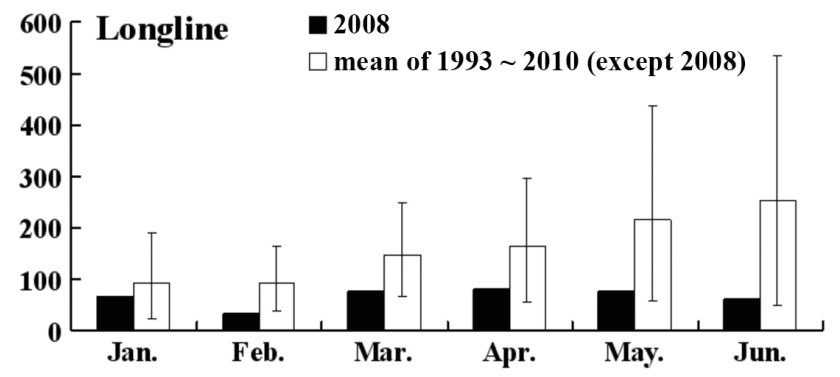

(d)

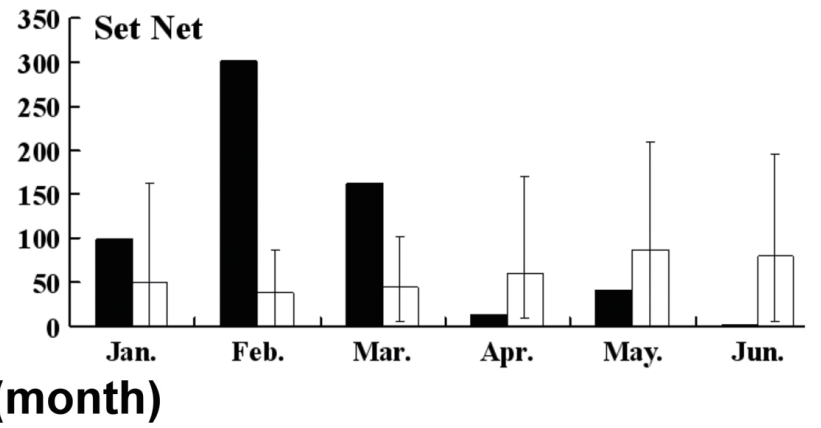

Fig. 7. Monthly catch variations of 4 major types of coastal fisheries in the Penghu area. Open bars: long-term average; solid bars: 2008; vertical, thin lines: range of monthly catches. 


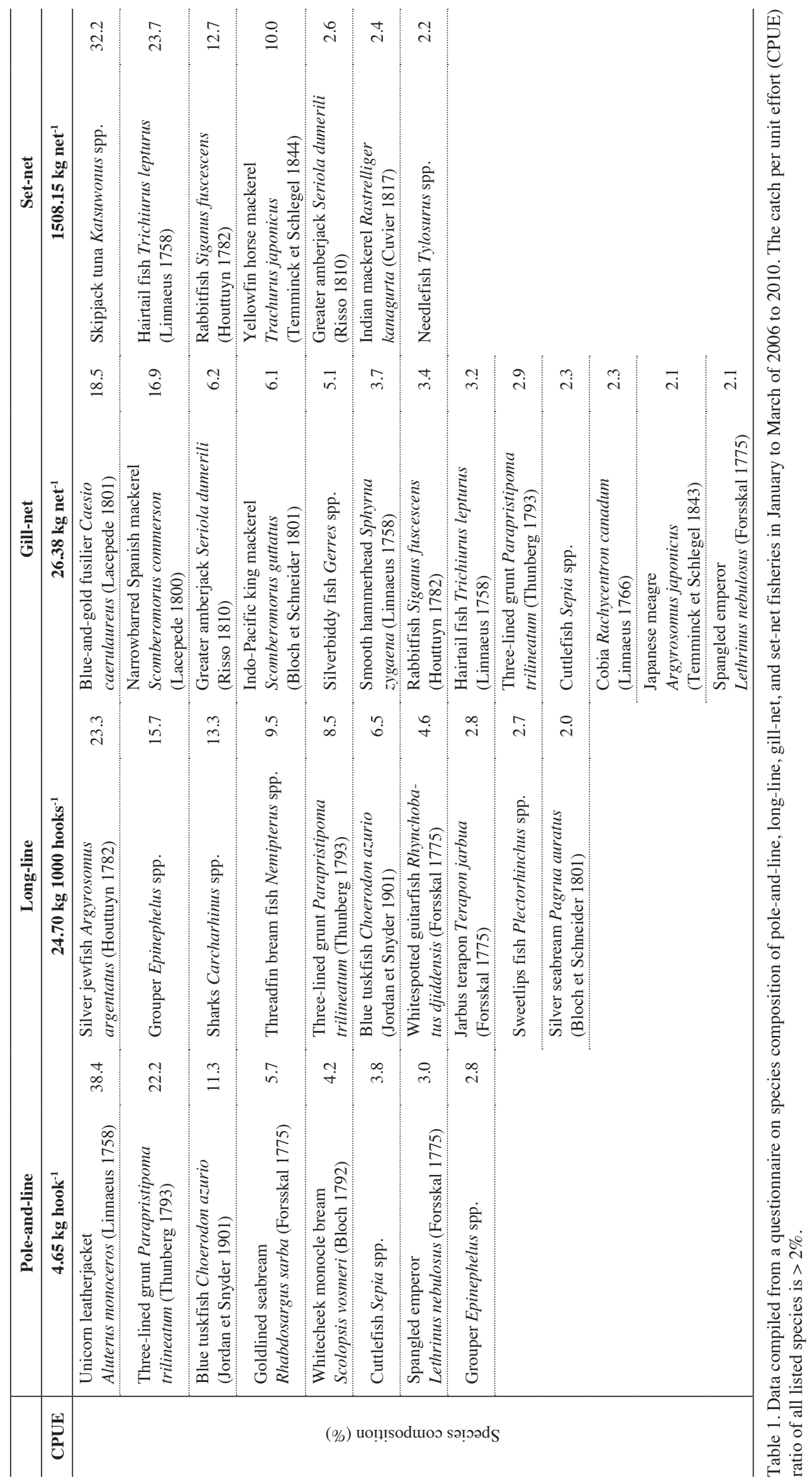


pole-and-line method. The Argyrosomus argentatus (silver jewfish, 23.3\%), Epinephalus spp. (grouper, 15.7\%), and Carcharhinus spp. (sharks, 13.3\%) were the dominant taxa of long-line method. Migratory species dominated the composition of the set-net fishery catch (over $85 \%$ of total catch). The pole-and-line, long-line, and gill-net methods accounted for primarily non-migratory species, approximately 54 - 100\% (Table 1).

A comparison of first quarter catches (January to March) between the La Niña years (1996, 1999 - 2001, and 2008) and the long-term averages (excluding 2008) indicate that pole-and-lines, gill-net, and long-line fisheries caught significantly less fish in 2008 (Table 2). Set-net fishery catches in 2000 and 2001 were slightly higher than the long-term average, but increased by approximately $230 \%$ in 2008. However, the catches of the other three types of fishing method decreased by approximately $50-80 \%$ in 2008. A $t$-test was used to compare the CPUE values of the 4 major species, skipjack tuna, hairtail fish, rabbitfish, and yellowfin horse mackerel, between 2008 and long-term averages. Table 3 shows that the CPUE was significantly dissimilar $(P<0.05)$ between 2008 and long-term average for skipjack tuna, hairtail fish, and rabbitfish and, significantly dissimilar for yellowfin horse mackerel. This suggests that the low-SST event caused a significant loss by fishing methods dependent on non-migratory species, but it led to a gain in the set-net method, dominated by migratory species.
Weekly variations in SST (derived from AVHRR in the area bounded by $23.5-24.0^{\circ} \mathrm{N}, 119.0-119.5^{\circ} \mathrm{E}$ ) and

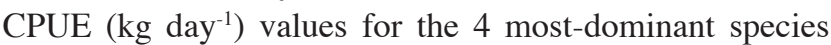
in the set-net method were used to evaluate the effect of the cold-water event on migratory species (Fig. 8). The 4-year average weekly CPUE (2006, 2007, 2009, and 2010, excluding 2008) of skipjack tuna (Fig. 8a; solid triangle) was higher when the SST was low (approximately $18^{\circ} \mathrm{C}$ ) in January and lower in February when the SST (Fig. 8a; solid circle) was higher (approximately $20-22^{\circ} \mathrm{C}$ ). However, the CPUE was significantly higher than the 4-year average in February 2008 (Fig. 8b), as the SST decreased to $14-16^{\circ} \mathrm{C}$ during the cold-SST event. Similar trends in CPUE were also noted in hairtail fish (Figs. 8c - d) and rabbitfish (Figs. $8 \mathrm{e}-\mathrm{f}$ ), but not in yellowfin horse mackerel (Figs. $8 \mathrm{~g}-\mathrm{h}$ ) which showed no difference in CPUE values before and during the cold-SST event in February 2008.

\section{DISCUSSION}

Satellite-derived SST and wind fields are parameters that can indicate important oceanic environmental dynamics related to currents, fronts, and climate change (Shimada et al. 2005). In general, cold water of $<14^{\circ} \mathrm{C}$ flows into the western TS along the Chinese coast during winter, but an eastward extension of cold water flows to the north of the CYR and blocks the northerly flow of warm water from

Table 2. Average quarterly (January-March) fish catch (metric tons) of 4 major coastal fisheries of the Penghu Islands of the long-term average of 1993 - 2010 (excluding 2008) and each of the La Niña years (1996, 1999, 2000, 2001, and 2008).

\begin{tabular}{ccccc}
\hline Fishing gear & Pole-and-line & Long-line & Gill-net & Set-net \\
\hline Average catch of 1993 - 2010 & 167.60 & 109.39 & 332.46 & 56.40 \\
1996 & 132.67 & 102.00 & 351.00 & 21.33 \\
1999 & 207.67 & 119.67 & 341.00 & 11.00 \\
2000 & 147.33 & 98.67 & 268.50 & 66.33 \\
2001 & 268.33 & 107.67 & 495.50 & 59.67 \\
2008 & 33.97 & 58.37 & 92.36 & 187.43 \\
\hline
\end{tabular}

Table 3. Statistical $t$-test of the February catches per unit effort (CPUE) for the 4 major species between 2008 and the long-term average.

\begin{tabular}{cccc}
\hline Species & $\begin{array}{c}\text { February 2008 } \\
(\text { CPUE kg net }\end{array}$ & $\begin{array}{c}\text { Long-term average for } \\
\text { February (CPUE kg net }^{-1} \text { ) }\end{array}$ & $\begin{array}{c}\boldsymbol{t} \text {-test } \\
\text { Skipjack tuna }\end{array}$ \\
Hairtail fish & 250.29 & 78.75 & $p<0.05$ \\
Rabbitfish & 109.88 & 49.59 & $p<0.05$ \\
Yellowfin horse mackerel & 105.79 & 41.67 & $p<0.05$ \\
\hline
\end{tabular}


(a)

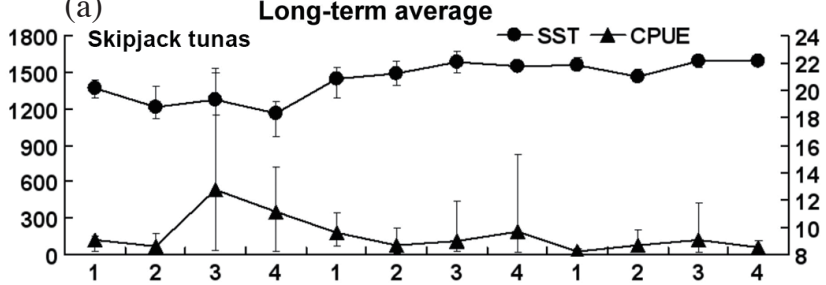

(c)

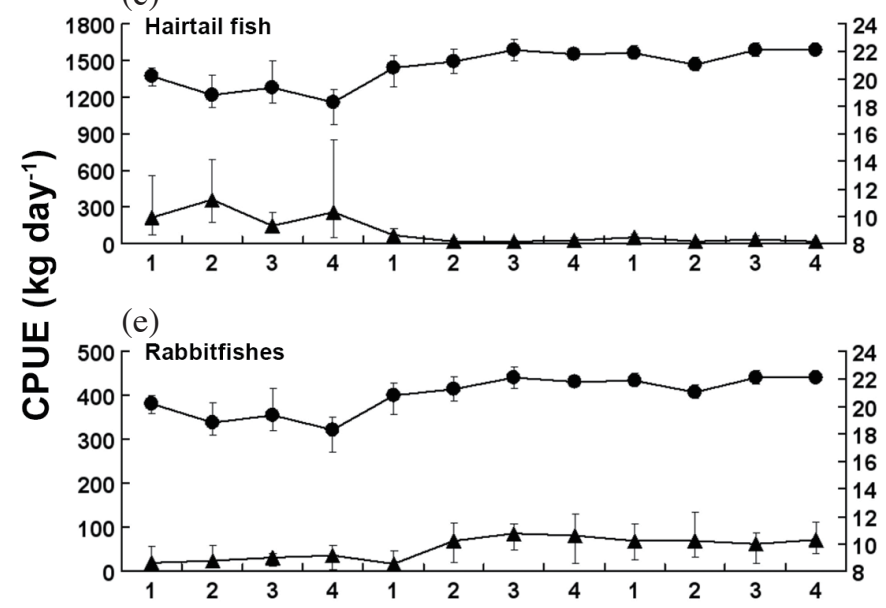

(g)

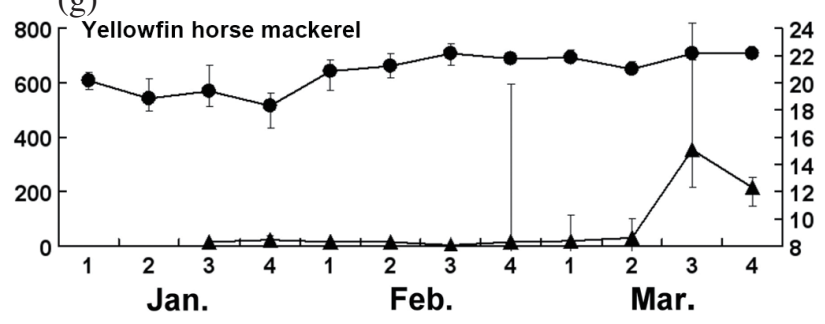

(b)

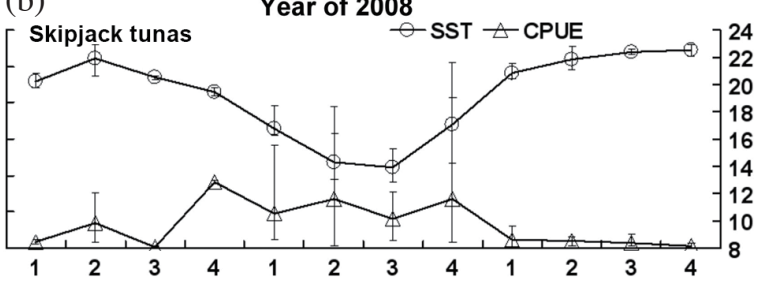

(d)

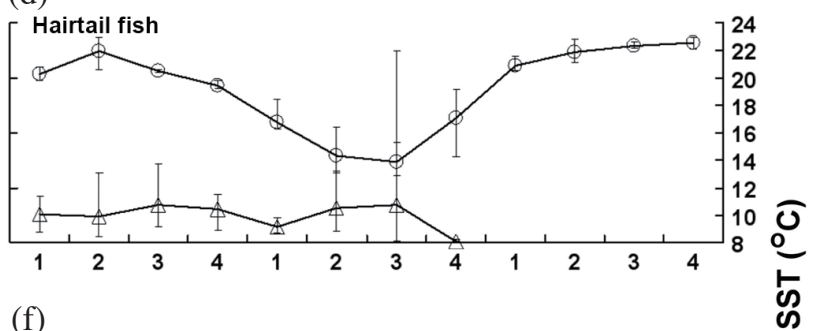

(h)

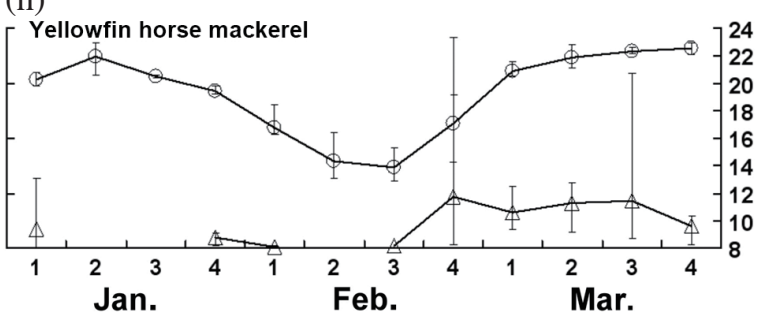

Time (week month-1)

Fig. 8. Weekly catch per unit effort (CPUE) of skipjack tuna (a - b), hairtail fish (c - d), rabbitfish (e - f), and yellowfin horse mackerel (g - h) in the set-net fishery (triangle) with satellite-derived sea surface temperatures (SST) (circle) of waters around Penghu Islands (PHI) (solid lines) in January to March from 2006 to 2010 (left panels) and 2008 (right panels).

the southeastern TS. The present study discovered a further southward extension of the cold water toward the waters around the PHI in February 2008 (Fig. 2e). This exceptional southerly intrusion of cold current caused a decrease in SST of approximately $8^{\circ} \mathrm{C}$. The cold CCC flowed more southerly and strong winds lasted longer during the $3 \mathrm{La}$ Niña winters of 1996, 2000, and 2008. These variations suggest that the wind speed in La Niña years plays a critical role in affecting the SST variations in the TS.

Kuo and Ho (2004) indicated that the northeasterly wind was significantly stronger in the La Niña winters of 1998 and 1999 than in the El Niño winters of 1997 and 1998. Chang et al. (2009) indicated that wind speed during the La Niña winter of 2008 sharply increased on January 26 (peaking at $7.36 \mathrm{~m} \mathrm{~s}^{-1}$ in February) and lasted for more than 3 weeks. Furthermore, they suggested that the continuous strong wind may have driven the cold current more south- easterly toward the southern TS, resulting in a significant decrease in SST. In accordance with Lee et al. (2005a) and Tzeng et al. (2012), we regarded the $20^{\circ} \mathrm{C}$ isotherm as a criterion to examine the trends and variations of the $\mathrm{CCC}$ and $\mathrm{KBC}$ or SCSWC in ENSO winters. The SST images with the $20^{\circ} \mathrm{C}$ isotherm were compared with the duration of $>6 \mathrm{~m} \mathrm{~s}^{-1}$ wind speeds (Fig. 4). The durations and high wind speeds of $>6 \mathrm{~m} \mathrm{~s}^{-1}$ were approximately 8 - 19 days during La Niña winters, but only $2-8$ days in El Niño winters. In 1996,2000 , and 2008 , the $20^{\circ} \mathrm{C}$ isotherms retreated southward to the PHI when high winds lasted more than 15 days. However, if high winds lasted 8 days or less than 8 days, the $20^{\circ} \mathrm{C}$ isotherms moved northward toward the northern TS. Therefore, the cold SST event did not occur in an El Niño winter. To provide a clearer view of this intrusion process, we examined the current and water temperature at a $20-\mathrm{m}$ depth as simulated by the HYCOM model, and the wind 
speed before and after the cold-water intrusion event in February 2008 (Fig. 9). Generally, a south-to-north pressure gradient exists in the TS, associated with large-scale circulation (Yang 2007). Thus, a northward current always flows through the PHC. In winter, under the influence of a strong northeasterly wind and with the aid of rising topography (CYR), the northward KBC is blocked at the CYR accompanied with a frontal genesis process (Jan et al. 2002). With the criteria for intensity and duration of the northeasterly wind, the cold CCC penetrates the CYR to reach the northern PHC. As shown in Fig. 9a, the strong northeasterly wind drives the cold water to penetrate the southern TS, indicating that the wind stress force could overcome the northward pressure gradient. According to Liao et al. (2013), during an initial stage an eastward geostrophic current is formed while the northward pressure gradient force remains dominant. This U-shaped current was absent in the HYCOM weekly composite result, which might be due to the rather small time scale of the first stage. However, an eastward extension of the cold water existed around the CYR. The warm water associated with the large-scale circulation accumulated in the southern strait and resulted in the formation of an anticyclone eddy with increasing temperature, because of the block in the northern PHC (Fig. 9b). As the pressure in the southern strait gradually grew, the wind stress became unable to maintain the southward movement of cold water. As a result, a northward current was present in the eastern part of the TS, while the wind speed remained strong. A weakening of the northeasterly unleashed the northward intrusion of the $\mathrm{KBC}$, and the $\mathrm{CCC}$ retreated to the western part of the strait, as shown in Fig. 9c.

Both the HYCOM result and the satellite SST image shown in Fig. 3 depict a stronger cooling in the CYR area. We can infer that the numerical model provides the possible cooling process. Because the topography effect is crucial in this case, the surface flow pattern might not reveal all of the relevant information, and the balance in the momentum equation requires further investigation. However, this is not the major purpose of the present paper which focuses on verifying the cooling feature with satellites and its possible influence on the fish communities and species in the TS.

A significant rapid change in the marine environment would affect marine ecology and fisheries. Fish catches, dominated by the non-migratory species of the pole-andline, long-line, and gill-net methods, decreased by approximately $50-80 \%$ of the long-term average during the cold SST event (Fig. 7). More than 73 tons of slow-swimming fish died in the coastal waters around PHI during this cold (a)

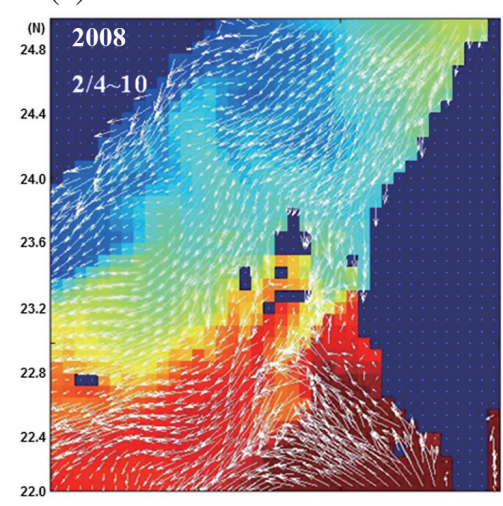

(d)

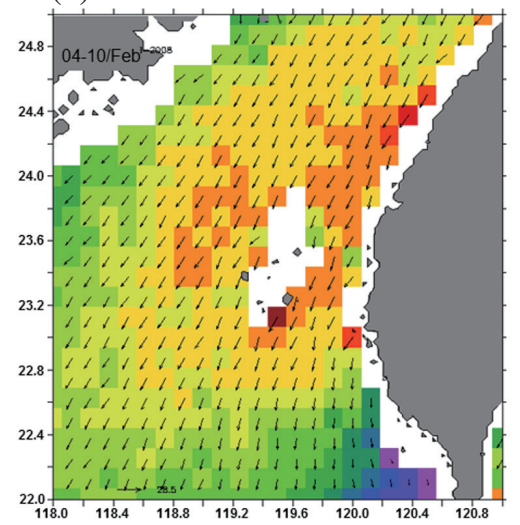

(b)

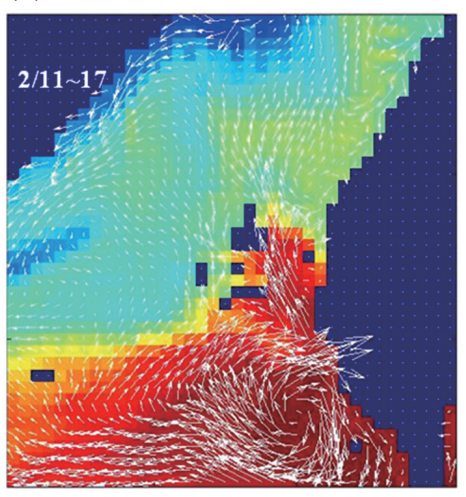

(e)

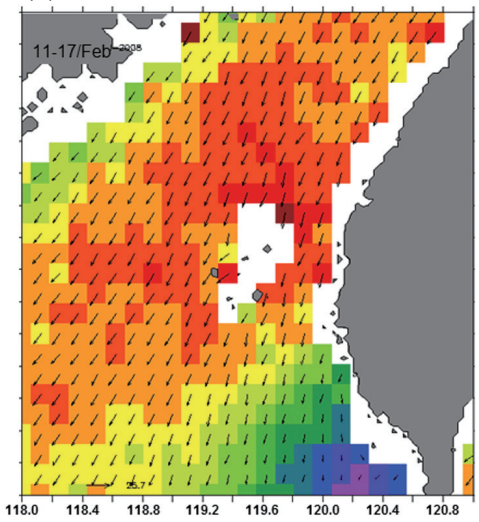

(c)

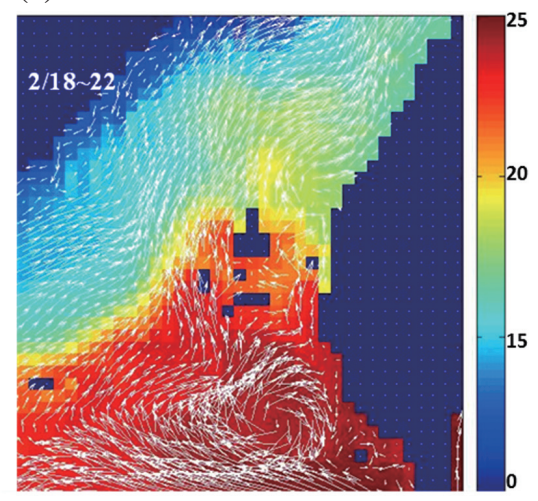

(f)

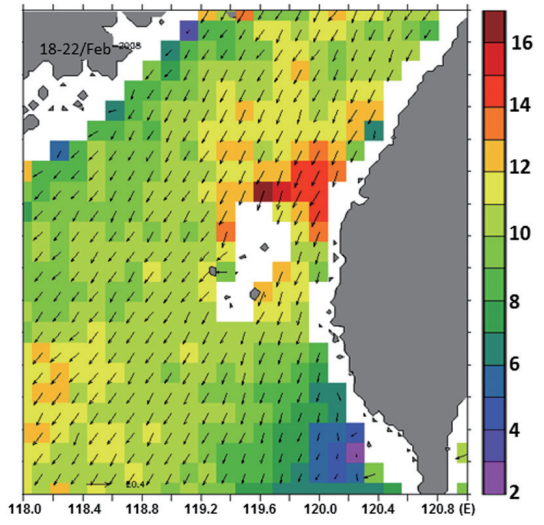

Fig. 9. HYCOM simulated weekly composite maps of water temperature at a 20-m depth with a superimposed current field at 20-m depth (a - c) and $(\mathrm{d}-\mathrm{f})$ wind vectors and speed $\left(\mathrm{m} \mathrm{s}^{-1}\right)$ of the corresponded period during the cold-water intrusion event. 
SST period. These fish comprised 183 species belonging to 58 families (Hsieh et al. 2008; Table 1). However, the overall effect of the cold SST on marine ecology and fisheries was not properly documented. Estimates of dead fish may not be accurate because fish sank to the sea floor, and no underwater data was collected during this cold SST period. The effects on the fisheries (especially on non-migratory species) in this study was similar to the findings of Wroblewski and Richman (1987),who reported that a certain mix of water and wind may have negative effects on nonmigratory species, because the turbulent environment may reduce feeding efficiency or drive fish away from their natural habitats. In the eastern Pacific Ocean, Mora and Ospina (2002) noted the negative effects of cold-water events in La Niña years on the composition and abundance of marine organisms, particularly on several reef fish when water temperatures fell below their critical thermal minimum $\left(16.3^{\circ} \mathrm{C}\right)$. Yoshitaka et al. (2000) observed the rhythm of the diurnal feeding activity of the Japanese spiny lobster (Panulirus japonicus) at $22^{\circ} \mathrm{C}$ and discovered a negative relationship between water temperature and feeding activity, especially when the water temperature gradually decreased from 23.3 to $7.9^{\circ} \mathrm{C}$. Lower water temperatures can result in fish mortality, especially when the temperature is below their critical minimum. Hill (1980) observed the mud crab (Scylla serrate) and indicated that feeding, duration of emergence, and movements remained stable between 20 and $25^{\circ} \mathrm{C}$, but clearly declined at $16^{\circ} \mathrm{C}$. Wolkenhauer (2008) indicated that the feeding activity of the sea cucumber (Holothuria scabra) was significantly and positively correlated with temperature, decreasing from $9.8 \mathrm{~h} \mathrm{~d}^{-1}$ at $24^{\circ} \mathrm{C}$ to $0.8 \mathrm{~h} \mathrm{~d}^{-1}$ at $17^{\circ} \mathrm{C}$. Thus, the exceptional cold SST in February 2008 may have impeded the feeding activities of warm-water and resident fish species. Low temperatures can affect immune functions and lead to loss of energy and nutrition because of reduced feeding activities (Le Morvan et al. 1998).

Although the exceptional intrusion of cold water may have had negative effects on coastal fisheries, it lured migratory species (Fig. 8). For instance, the catch of skipjack tuna was higher in the coldest SST period in February 2008 compared to the warmer SST period of 2006, 2007, and 2009. Chiou and Lee (2004) indicated that the skipjack tuna is widely distributed in the waters between the Philippines and Taiwan. It prefers to remain in waters with temperatures below $25^{\circ} \mathrm{C}$ and migrate to coastal waters for feeding. Lehodey et al. (1997) suggested that the convergence and fronts are important areas favorable for the aggregation of plankton and micronekton; consequently, they attract larger predators, such as skipjack tuna. A sharp frontal band $\left(>0.3^{\circ} \mathrm{C} \mathrm{km}^{-1}\right)$ acted as a boundary between the cold CCC and warm KBC and SCSWC (Fig. 2b) in our study area, providing a favorable environment for plankton aggregation and creating a feeding ground for skipjack tuna around the PHI in winter. As the cold-water intrusion extended to the PHI, the front vanished and the environment became unfavorable for skipjack tuna. Therefore, schools of skipjack tuna responded to the displacement of the frontal zone and congregated in coastal waters. This may explain the increased catch of skipjack tuna in February 2008. The skipjack tuna may have migrated southward during the cold SST event and quickly reversed their migration route toward the PHI for feeding as the cold CCC retreated to the Chinese coast. Pelagic fish, such as tuna, do not respond to temperature differences alone, but often swim to areas that provide forage. Primary oceanic production does not provide a direct link between feeding and the presence of tuna, but it provides an indicator of the bottom-up transfer of energy to organisms at higher trophic levels which tuna then consume. However, mechanisms of the SST front to provide the necessary bait biomass for the skipjack tuna should be further investigated.

Benthic hairtail fish are capable of migrating to warmer waters, coral reefs, and estuaries (Shen et al. 1993). Our data indicate that the catch of hairtail fish increased during the cold SST period. Kim and Rho (1998) stated that the spawning season of hairtail fish in the ECS is from April to August, with a peak in June. Migration of this species is considered to occur between the wintering grounds in the ECS and spawning grounds in the Yellow Sea (Shih 2004). In addition, Shih (2004) indicated that hairtail fish are normally distributed in the ECS but migrate to the TS and SCS for spawning in winter. Moreover, the set-net method caught significant amounts of rabbitfish in the southeastern waters of the PHI. This is in accordance with Yamaguchi et al. (2006), who indicated that the gut contents of rabbitfish were fuller at $18-23^{\circ} \mathrm{C}$ than at $14-19^{\circ} \mathrm{C}$; that is, cold-water intrusion positively affected the feeding activity and movement route of the rabbitfish. Speculation on the possible effect of the cold-water event on yellowfin horse mackerel is not possible because of insufficient catch data.

\section{CONCLUSION}

The strong and continuous northeasterly winds caused by the La Niña event during the winter of 2008 may have driven the cold CCC further southward to the southern TS around PHI. The duration of wind speeds of $>6 \mathrm{~m} \mathrm{~s}^{-1}$ during La Niña winters may affect the cold SST intrusions into the TS. However, clarification of the relationship between the cold-water intrusion and wind speeds during the La Niña winter is difficult. Using durations of strong winds and satellite-derived SST images in hydrologic models may provide useful information to understand the mechanism of cold-water intrusions during La Niña winters. Therefore, analysis of in-situ and satellite data, and the development of modeling simulations, should be undertaken to improve and comprehend such exceptional SST variations in the TS.

The low-SST event significantly impeded marine 
life and caused the death of resident fish, coral reef fish, and slow-swimming fish. However, it attracted migratory species from colder water, suggesting that this event simultaneously created positive and negative effects on fish communities and species. The mechanism of cold-water intrusion may need to be further investigated by modeling simulations, using field data with high spatial resolution. Future development of an early warning system to alert us to the advent of an ecological disaster, such as cold-water intrusion, is highly desirable. The analyses of in-situ data combined with modeling simulations may be undertaken to improve the understanding of the causes and precursors of exceptional SST variations in the TS. Various effects of climate change on wind fields should be further investigated.

Acknowledgements This study was supported by a research grant of the Center for Marine Bioenvironment and Biotechnology, National Taiwan Ocean University (NTOU). The National Science Council (NSC98-2611-M-019-008) and the Council of Agriculture (98AS-8.5.2-FA-F1), Taiwan, provided further grants. The authors would like to express their appreciation to Prof. Chang-Tai Shih of NTOU for his helpful advice on this manuscript.

\section{REFERENCES}

Akiyama, H. and S. I Saitoh, 1993: The Kyucho in Sukumo Bay induced by Kuroshio warm filament intrusion. $J$. Oceanogr., 49, 667-682, doi: 10.1007/BF02276751. [Link]

Anonymous, 2008: Investigations of marine ecology and fishery resources in Peng-Hu waters. 2008 Annual Report of Fishery Agency, December 2008, Taipei, Taiwan, $394 \mathrm{pp}$.

Bleck, R., 2002: An oceanic general circulation model framed in hybrid isopycnic-Cartesian coordinates. Ocean Model., 4, 55-88, doi: 10.1016/S14635003(01)00012-9. [Link]

Chang, Y., T. Shimada, M. A. Lee, H. J. Lu, F. Sakaida, and H. Kawamura, 2006: Wintertime sea surface temperature fronts in the Taiwan Strait. Geophys. Res. Lett., 33, L23603, doi: 10.1029/2006GL027415. [Link]

Chang, Y., K. T. Lee, M. A. Lee, and K. W. Lan, 2009: Satellite observation on the exceptional intrusion of cold water in the Taiwan Strait. Terr. Atmos. Ocean. Sci., 20, 661-669, doi: 10.3319/TAO.2008.08.07.01(Oc). [Link]

Chang, Y., M. A. Lee, K. T. Lee, and K. T. Shao, 2013: Adaptation of fisheries and mariculture management to extreme oceanic environmental changes and climate variability in Taiwan. Mar. Policy, 38, 476-482, doi: 10.1016/j.marpol.2012.08.002. [Link]

Chiou, W. D. and L. K. Lee, 2004: Migration of kawakawa Euthynnus affinis in the waters near Taiwan. Fisheries Sci.,
70, 746-757, doi: 10.1111/j.1444-2906.2004.00867.x. [Link]

Edwards, M., G. Beaugrand, P. C. Reid, A. A. Rowden, and M. B. Jones, 2002: Ocean climate anomalies and the ecology of the North Sea. Mar. Ecol. Prog. Ser., 239, 1-10, doi: 10.3354/meps239001. [Link]

Hill, B. J., 1980: Effects of temperature on feeding and activity in the crab Scylla serrata. Mar. Biol., 59, 189192, doi: 10.1007/BF00396867. [Link]

Hsieh, H. J., Y. L. Hsien, and W. S. Tsai, 2008: Tropical fishes killed by the cold. Coral Reefs, 27, 599, doi: 10.1007/s00338-008-0378-3. [Link]

Jan, S., C. S. Chern, and J. Wang, 1998: A numerical study of currents in the Taiwan Strait during winter. Terr. Atmos. Ocean. Sci., 9, 615-632.

Jan, S., J. Wang, C. S. Chern, and S. Y. Chao, 2002: Seasonal variation of the circulation in the Taiwan Strait. J. Mar. Syst., 35, 249-268, doi: 10.1016/S09247963(02)00130-6. [Link]

Kim. S. H. and H. K. Rho, 1998: A study on the assembling mechanism of the hairtail, Trichiurus lenpturus, at the fishing grounds of the Cheju Strait. Bull. Korean Soc. Fish. Technol., 34, 117-134.

Knutson, T. R., J. L. McBride, J. Chan, K. Emanuel, G. Holland, C. Landsea, I. Held, J. P. Kossin, A. K. Srivastava, and M. Sugi, 2010. Tropical cyclones and climate change. Nat. Geosci., 3, 157-163, doi: 10.1038/ ngeo779. [Link]

Kuo, N. J. and C. R. Ho, 2004: ENSO effect on the sea surface wind and sea surface temperature in the Taiwan Strait. Geophys. Res. Lett., 31, L13309, doi: 10.1029/2004GL020303. [Link]

Le Morvan, C., D. Troutaud, and P. Deschaux, 1998 : Differential effects of temperature on specific and nonspecific immune defences in fish. J. Exp. Biol., 201, 165-168.

Lee, M. A., C. D. Yeah, C. H. Cheng, J. W. Chan, and K. T. Lee, 2003: Empirical orthogonal function analysis of AVHRR sea surface temperature patterns in Taiwan Strait. J. Mar. Sci. Tech.-Taiw., 11, 1-7.

Lee, M.A., Y.Chang, F. Sakaida,H. Kawamura, C. H.Cheng, J. W. Chan, and I. Huang 2005a: Validation of satellitederived sea surface temperatures for waters around Taiwan. Terr. Atmos. Ocean. Sci., 16, 1189-1204.

Lee, M. A., Y. Chang, K. T. Lee, J. W. Chan, D. C. Liu, and W. C. Su, 2005b: A satellite and field view of the winter SST variability in the Taiwan Strait. Proceedings of IEEE IGARSS 2005, 4, 2621-2626, doi: 10.1109/ IGARSS.2005.1525524. [Link]

Lehodey, P., M. Bertignac, J. Hampton, A. Lewis, and J. Picaut, 1997: El Niño Southern Oscillation and tuna in the western Pacific. Nature, 389, 715-718, doi: 10.1038/39575. [Link]

Liao,E., Y.Jiang, L. Li, H. Hong, and X. Yan, 2013: The cause of the 2008 cold disaster in the Taiwan Strait. Ocean 
Model., 62, 1-10, doi: 10.1016/j.ocemod.2012.11.004. [Link]

Liu, K. K., T. Y. Tang, G. C. Gong, L. Y. Chen, and F. K. Shiah, 2000: Cross-shelf and along-shelf nutrient fluxes derived from flow fields and chemical hydrography observed in the southern East China Sea off northern Taiwan. Cont. Shelf Res., 20, 493-523, doi: 10.1016/ S0278-4343(99)00083-7. [Link]

Lloret, J., A. Marín, and L. Marín-Guirao, 2008: Is coastal lagoon eutrophication likely to be aggravated by global climate change? Estuar. Coast. Shelf Sci., 78, 403-412, doi: 10.1016/j.ecss.2008.01.003. [Link]

McClain, E. P., W. G. Pichel, and C. C. Walton, 1985: Comparative performance of AVHRR-based multichannel sea surface temperatures. J. Geophys. Res., 90, 1158711601, doi: 10.1029/JC090iC06p11587. [Link]

Mora, C. and A. F. Ospina, 2002: Experimental effect of cold, La Niña temperatures on the survival of reef fishes from Gorgona Island (eastern Pacific Ocean). Mar. Biol., 141, 789-793, doi: 10.1007/s00227-002-0862-1. [Link]

Pan, J., X. H. Yan, Q. Zheng, W. T. Liu, and V. V. Klemas, 2002: Interpretation of scatterometer ocean surface wind vector EOFs over the Northwestern Pacific. Remote Sens. Environ., 84, 53-68, doi: 10.1016/S00344257(02)00073-1. [Link]

Parsons, L. S. and W. H. Lear, 2001: Climate variability and marine ecosystem impacts: A North Atlantic perspective. Prog. Oceanogr., 49, 167-188, doi: 10.1016/ S0079-6611(01)00021-0. [Link]

Shen, S. C., S. C. Lee, K. T. Shao, C. T. Chen, H. K. Mok, and C. H. Chen, 1993: Fishes of Taiwan. Department of Zoology, National Taiwan University, 960 pp.

Shih, N. T., 2004: Age, growth and reproduction of cutlassfishes, Trichiurus spp. in the waters off Taiwan. Master Thesis, Department of Environmental Biology and Fisheries Science, National Taiwan Ocean University, Keelung, Taiwan, $101 \mathrm{pp}$.

Shimada, T., F. Sakaida, H. Kawamura, and T. Okumura, 2005: Application of an edge detection method to satellite images for distinguishing sea surface temperature fronts near the Japanese coast. Remote Sens. Environ., 98, 21-34, doi: 10.1016/j.rse.2005.05.018. [Link]

Takasuka, A., Y. Oozeki, and I. Aoki, 2007: Optimal growth temperature hypothesis: Why do anchovy flourish and sardine collapse or vice versa under the same ocean regime? Can. J. Fish. Aquat. Sci., 64, 768-776, doi: 10.1139/f07-052. [Link]

Tang, T. Y., J. H. Tai, and Y. J. Yang, 2000: The flow pattern north of Taiwan and the migration of the Kuroshio. Cont. Shelf Res., 20, 349-371, doi: 10.1016/S02784343(99)00076-X. [Link]

Tzeng, M. T., K. W. Lan, and J. W. Chan, 2012. Interannual variability of wintertime sea surface temperatures in the eastern Taiwan Strait. J. Mar. Sci. Technol., 20, 707-712, doi: 10.6119/JMST-012-0913-1. [Link]

Wang, J. and C. S. Chern, 1992: On the distribution of bottom cold waters in Taiwan Strait during summertime. La mer, 30, 213-221.

Wang, B., R. Wu, and X. Fu, 2000: Pacific-East Asian teleconnection: How does ENSO affect East Asian climate? J. Climate, 13, 1517-1536, doi: 10.1175/1520-0 442(2000)013<1517:PEATHD>2.0.CO;2. [Link]

Wolkenhauer, S. M., 2008: Burying and feeding activity of adult Holothuria scabra (Echinodermata: Holothuroidea) in a controlled environment. SPC Beche de Mer Inform. Bull., 27, 25-28.

Wroblewski, J. S. and J. G. Richman, 1987: The non-linear response of plankton to wind mixing events - implications for survival of larval northern anchovy. J.Plankton Res., 9, 103-123, doi: 10.1093/plankt/9.1.103. [Link]

Yamaguchi, A., K. Inoue, K. Furumitsu, T. Kiriyama, T. Yoshimura, T. Koido, and H. Nakata, 2006: Behavior and migration of rabbitfish Siganus fuscescens and grey seachub Kyphosus bigibbus off Nomozaki, Kyushu, tracked by biotelemetry method. Nippon Suisan Gakk., 72, 1046-1056, doi: 10.2331/suisan.72.1046. [Link]

Yang, J., 2007: An oceanic current against the wind: How does Taiwan Island steer warm water into the East China Sea? J. Phys. Oceanogr., 37, 2563-2569, doi: 10.1175/JPO3134.1. [Link]

Yatsu, A., T. Watanabe, M. Ishida, H. Sugisaki, and L. D. Jacobson, 2005: Environmental effects on recruitment and productivity of Japanese sardine Sardinops melanostictus and chub mackerel Scomber japonicus with recommendations for management. Fish. Oceanogr., 14, 263-278, doi: 10.1111/j.1365-2419.2005.00335.x. [Link]

Yoshitaka, M., A. Hisayuki, and K. Takashi, 2000: Effects of water temperature on diurnal feeding activity of Japanese spiny lobster Pannlirus japonicus. Nippon Suisan Gakk., 66, 791-798. 